LECH STACHOWIAK

\title{
How We Should Interpret Bible Verses About Man*
}

Modern theology always addressed biblical scholars with a question on the structure and role of man in the written messages of Revelation. From the moment when man took first a prominent, and later a rather fundamental place in theological reflection, the question started to acquire a completely new meaning. Most often it was about the confrontation of philosophical, psychological or even anthropological assumptions of theology with biblical data. Typical problems still debated today ${ }^{1}$, were the relationship between the biblical and Greek-Hellenistic view on the structure of man.

It was discussed whether there was a specifically biblical view on man, how it possibly differed from general Semitic patterns, and whether and to what extent the encounter of revealed thought with the world of Hellenistic culture led to a change of views on man in the Old and New Testaments.

These questions were answered in accordance with the assumed hermeneutic assumptions of biblical teachings. First, all Bible data was collected about a man, his life, the operation of his organs, about his superior and religious life, about his death or about the continuation of his existence. It is not the task of this paper to present in extenso, or even outlining the interesting attempts that paved the way for the development of a more contemporary biblical anthropology ${ }^{2}$. It is only worth recalling some of the classic themes of this stage of biblical reflection that have been kept up to date. Are we, therefore, justified to say that

STV 12(1974)1.

1 Cf. A.M. Dubarle, La Bible a-t-elle une doctrine sur l'âme et le corps?, "Recherches et debates" 35(1961), 1803-2000; H. Haag, P. Möhrers, Ursprung und Wesen des Menschen, Tübingen 1966; L. Stachowiak, Biblijna koncepcja człowieka (monizm czy dualizm?), in: W nurcie zagadnień posoborowych, vol. 2, Warsaw 1968, 209-226.

2 A review of contemporary problems of theological anthropology with a comprehensive bibliography is provided by J. Krasiński, Rola antropologii w teologii dogmatycznej, "Antropocentryczny zwrot”, AK 79(1962), 152-170. 
according to the specifically biblical concept of man, which is assumed by this biblical reflection, man is considered as one indivisible psychophysical entity, or can one speak of an anthropological complexity?

Are there traces of anthropological duality present in the biblical scriptures, also well known in non-biblical circles? What is the basic meaning of anthropological concepts in the Bible? These questions require not so much new answers as deeper theological justifications. The same should be stated about the conclusions of biblical anthropology, both negative and positive.

It has long been evident that biblical writings of such different prehistory, written in such a considerable period of time and in such different circumstances, assume very diverse data about man. What is more, none of the books presents even basic theoretical principles of anthropology, but only occasional statements. They concern only specific manifestations of man's religious life, and it is the latter and not man himself which constitutes the main subject of interest of authors. Compiling these statements that assume very different, chronologically, locally and essentially life situations into one whole could easily lead to an artificial biblical image of a human being. Such a picture would not fully correspond to any of the individual statements. Therefore, modern biblical anthropology requires slightly different hermeneutic principles. Research on the structure of man, or its main point of interest, which it has not given up, was replaced by research on his relationship to God and the world, on attempts to understand his religious existence, his role in the community of the old and new God's people, and ultimately on the ethical consequences resulting from it.

Such a view reveals many new values, specifically theological, susceptible to confrontation with contemporary reality. Thus, it provides a more complete answer to questions currently posed by theology and fulfills the role of not only the source but also the link between its various factions. An in-depth look at the role of man in the Bible is a consequence of various factors, partly independent of each other. Contemporary biblical criticism has presented many biblical statements in a completely new light. First, it found in the Bible a series of parallel traditions that often had a long history; their view of man was different, it was subject to development, criticism and even devaluation. Today, there is no doubt that one cannot ascribe the analogous concept of man to the wisdom and prophetic tradition, just as one cannot identify the different views on a man which are assumed in the Jewish, Elohistic and priestly tradition ${ }^{3}$.

3 This was demonstrated convincingly by J. Scharbert, Fleisch, Geist und Seele im Pentateuch, Stuttgart 1967. 
Each requires careful monographic development, which would indicate apart from only a few common components of man - independent reflection, confrontation with other views or their criticism.

Let us refer to the one example which confirms that the man of the wisdom tradition, the man of the book of Proverbs essentially realizes the ideals of temporal happiness identified from time to time with the fear of God, whereas in the Psalms such an attitude is criticized in favor of a purely religious attitude that imposes the faithful life with God and total dependence on Him. The problem of anthropology is even more complicated in wisdom books characterized by polemical tendencies, such as the Book of Job or the Book of Ecclesiastes. The latter even takes a formal polemic with contemporary ideas about the role of the life-giving factor of man and his fate: "Who knows the spirit of man, whether it goes upward, and the spirit of the animal, whether it goes downward to the earth?"4

In this difficult task of biblical anthropology, historical-literary considerations proved to be helpful. They have often led to the true origin of certain views on man, to their theological origin, and thus allowed to establish the original contribution of revealed thought to anthropology. The history of the editions has taught us to recognize in the individual layers of the inspired books traces of subsequent, sometimes conflicting views. In turn, the existential approach determined by philosophy made the Bible scholar interpret statements of Scripture about man from a slightly different point of view.

It drew attention to texts that did not say a great deal or nothing about the internal structure of a human being, but which pointed to the assumptions obvious to the world of the time. The collection of these assumptions, as far as it concerns understanding man by himself in the world of his culture and modernity, technically referred to by the German term Selbstverständnis ${ }^{5}$, often allows a much deeper insight into biblical anthropology than a set of formal data from the entire Bible about man, collected and systematically classified, can do. In any case, both ways of reconstructing the image of man are complementing and verifying each other. The new look of post-conciliar theology proved in an irrefutable way that the tasks of the Bible also include determining the anthropological background of sin, justifying the phenomenon of eternal life and resurrection, and moreover, many Christological statements. The anthropological

4 Ecclesiastes 3:21. Kohelet seems to fight the first indications (appearing in the biblical books only in the Maccabean period) of anthropological speculation about eternal life. Cf. R. Kroeber, Der Prediger, Berlin 1963, 136.

${ }_{5} \quad$ This term originated in circles of existential German theology and was then adopted in all modern theology, both non-Catholic and Catholic. 
conclusions of the biblical scholar often belong to the field of dogmatic, moral theology or internal life. Of course, the various aspects of theology differ in terms of the methods of scientific work, hermeneutic principles, arguments, but nevertheless they pursue one goal.

Therefore, the following considerations will not be a lecture of biblical anthropology in its most important assumptions, but an attempt to indicate the method of anthropological interpretation of basic biblical statements. Above all, it should be noted that in its statements, the Bible never practically refers to the abstract concept of man or humanity. Man is always regarded as an individual - although often regarded as a member of the community - living in the world, but connected with God and other people, by multiple relationships. Even very general statements as for example those referring to God's anthropopathic grief over the creation of man (Genesis 6:6) or statements regarding the limitedness of his life (Genesis 6:3) relate not to human nature, but to people considered as rebellious with regard to God and those who lead a life that stands in opposition to His salvific will ${ }^{6}$.

As the basis of man's unity and solidarity with regard to reward, responsibility or suffering one should therefore consider not the (commonly accepted in the pagan world) awareness of belonging to the same human race $^{7}$, but being a member of one theocratic People of God, bound by the same covenant with God, endowed with the same Law, conducting the same dialogue with God in its history. This dialogue between the God-Creator and man, a member of His community, has a personal character. It is characterized by a specific dialectic.

On the one hand, granted a place over all creation as being the image of God (Genesis 1:26), man rules over all the superior beings, and on the other, he appears to be an impotent creature, craving for the uplifting gift of God. These are, however, not two genetically different concepts born in different theological environments, but appearing in the Bible in various proportions, depending on the historic-redemptive and historical conditions of God's People. Today, it is not enough to say that this dialogue oscillates between three strictly anthropological elements: spirit, life-giving element and body ${ }^{8}$; it is also not enough

6 More extensive commentary on Genesis 6.1-4 is provided by J. Scharbert, Traditions und Redaktionsgeschichte von Gn 6, 1-4, BZ NF 11(1967), 66-78.

7 In the most exhausting manner in the poetic form it was formulated by Terence (Heautontim, 1.1): Homo sum, humani nil a me alienum puto.

${ }^{8}$ Basic information on this topic is provided by modern encyclopedias and biblical dictionaries - see especially Mysterium Salutis vol. 2, Einsiedeln 1967, 584-602 and Sacramentum Mundi vol. 1, Freiburg 1968, 168-176. The Polish translation of the modern Dictionary of Biblical Theology is in print. Also worth noting are the relevant entries developed in Theologische Wörterbuch 
to state that in the each of these three elements the entire personality of a man can be manifested. Biblical anthropology rather deals with the theological consequences of the role of each of them. What is the meaning of nefes - the life-giving force - with regard to the religious existence of a human being? If it seems to assume a certain orientation in life ${ }^{9}$, then in what sense is it susceptible to confrontation with the Greek psyché, which, after all, is necessarily undertaken in the New Testament? Should its role in the new reality of salvation and rejection be understood as "neutral" in the sense assumed in Old Testament, or rather as a subject of new life, which is only threatened by eschatological death? ${ }^{10}$

If rûh (spirit) expresses a man living in the spirit of God's charismatic action $^{11}$, and in any case as the creature, which has been granted divine characteristics, then one could ask in what relation to him and his personality remains the transcendent Spirit of Saint John, the Paraclete, the witness of $\operatorname{truth}^{12}$ and the world of other transcendent spirits ${ }^{13}$ ? An extremely important issue in inter-testamental ethics and one presented in New Testament, where the spirit plays a dominant role, will be to establish the meaning of the term pneuma. The moral evaluation of behavior will be different if it is understood as a transcendent factor or as an aspect of the personality of a subject who is supported intensively by this Spirit. The ease with which non-biblical Qumran ${ }^{14}$ and inter-testamental

zum Neuen Testament (sarx, 98-151, soma, 1024-1091, the article on psyche is under preparation) and in Theologische Wörterbuch zum Alten Testament (article concerning bśr - vol. 1, 850-867; jś - ibid., 238-252).

9 Cf. W. Schmidt, Anthropologische Begriffe im Alten Testament, "Evang. Theologie" 24(1964), 374-388, esp. 371-381.

10 Contemporary biblical anthropology tends to understand death as a natural consequence of the limitedness of human existence. Some later texts - especially of apocalyptic origin - perceive death in the sense of a definitive eschatological rejection ("second death") S. Haag (Biblische Schöpfungslehre und kirchliche Erbsündenlehre, Stuttgart 1967, 55) also includes in this category the statement of Wisdom 2:24.

11 This aspect is particularly emphasized by the Jahwist tradition. In addition, the "spirit" (rûh) may mean an exponent of the religious life of man, which later (in the Deuteronomic tradition) is defined by the "life-giving element" (nefes). For further details see J. Scharbert, Fleisch, Geist und Seele, 80.

12 Cf. A.M. Kothgasser, Dogmenentwicklung und die Funktion des Geistparakleten nach den Aussagen des II. Vatikanischen Konzils, Rome 1969; J.B. Patrick, The Promise of the Paraclete, "Biblioth. Sacra" 127 (1970), 333-345.

13 Cf. P. van Imschoot, Geist, BL Einsiedeln 1968, 535-536.

14 Cf. esp. F. Nötscher, Geist und Geister in den Texten von Qumran, in: Mélanges Bibliques en l'honneur de A. Robert, Paris 1959, 305-315; L. Stachowiak, Teologiczny temat dwóch duchów w pismach ąumrańskich, "Zeszyty Naukowe KUL” 10(1967), 37-52. 
literature passes from the transcendent sense to the anthropological "spirit" confirms that the authors were concerned with the supreme God's salvific action. In any case, these anthropological considerations on the role of the spirit are a fruitful introduction to the theology of the residence of the Holy Spirit in the soul of a Christian (see Rom 8:11). The body as an expression of solidarity between people is an exponent of the weakness and transience of a human being considered in its extreme form as a radical opposition to God.

The latter will be developed only in inter-testamental anthropology and the one presented in New Testament, whereas in the Old Testament the body is considered as expressing first of all the situation of man as being created as inferior with regard to God and, therefore, as a creature of limited existence ${ }^{15}$, Sir 17:1-2 speaking about the creation of man by God states that despite the power and likeness of man to God, the life of people lasts a certain number of days, and each of us has a predetermined time of existence. The body understood in this way is neither an anthropological source nor a subject of sin, but it is most susceptible to sin. Both the Old Testament and the New Testament assume that the decision about committing sin begins in the heart: a decision in favor or against the will of God is made and is maturing there ${ }^{16}$.

Nevertheless, for the author of this very old text of Genesis 6:3, probably having its origin in the sacerdotal tradition, the body is considered a threat to the "spirit" understood as God's power granted to man for the whole period of his life ${ }^{17}$. Neither the original form of the text nor its re-reading during the period of Babylonian captivity ${ }^{18}$ presents the body as an active anthropological factor encouraging committing a sin. The fundamental change will be introduced only by the Apocalyptic and the New Testament, replacing the theological justification of the relationship of man to God with the concept of two spheres of worldliness falling under the rule of Satan, which exposes the body and the sphere of God, and whose exponent is the spirit.

Interpreting the anthropological conditions of sin, we must not forget that the earliest written evidence emphasizes rebellion against God, primarily

15 Cf. Mysterium Salutis, op. cit., $593 f$.

16 Cf. J. Schreiner, Persönliche Entscheidung vor Gott nach biblischem Zeugnis, "Bibel und Leben" 6(1965), 112-115.

17 J. Scharbert, Traditions..., op. cit., 74 holds that the author of the statements probably understood both anthropological factors as being in a sense contradictory.

18 In its present form, the text of Gen. 6:1-4 can probably be dated to the time of Ezekiel's writings, with which it shows certain some similarities (see Ez 37:6). The editorial history of this text is considered disputable. 
as a fact - and a decisive fact - introducing disharmony into God's saving intentions. The anthropological assumptions serve more to illuminate the background of the event than provide its justification or cause ${ }^{19}$ : the body made it possible for humans to become entangled in sin, it is considered a convenient area for its development ${ }^{20}$. Subsequent speculations about two spirits fighting for domination in man's soul ${ }^{21}$, two inclinations, or jesarim ${ }^{22}$, are only an anthropological attempt to justify the ethical dilemma of man, analogous to the concept of the two spheres: God and Satan.

Commenting on the anthropological statements of the New Testament, one must remember three basic assumptions. The first is the fundamental continuation of the anthropological Old and inter-testamental line as far as its basic structure is concerned. Authors who wrote in Greek partly out of necessity, partly deliberately, use new terms typical for Greek anthropology, such as "soul" (psyché), "reason" (nous), "conscience" (syneidesis), etc. However, these are not completely new terms from the point of view of biblical tradition; they were partly prepared by LXX, and even to a greater extent by the non-canonical inter-testamental literature that continued the development of Old Testament anthropology. However, the confrontation of biblical and Greek-pagan content is neither homogeneous in these texts nor in the New Testament, so the meaning of statements about the "soul" (psyché) in the sense more similar to the Hebrew nefes or Hellenistic psyché, considered as autonomous and immortal, must be determined by reliable, modern exegesis, not by a priori anthropological principles.

To quote only one of the more difficult examples, Matthew 10:28 warns his readers not to have fear in relation to those who kill the body, but who cannot kill the soul, and recommends to fear those because of whom body and soul can be lost in hell. In the first part of the statement - as it seems - a specifically

19 R. Pesch (Anthropologie, in: Sacramentum Mundi vol. 1, 171) writes on the subject as follows: "However, the occurrence of sin in the Bible is rather an ontic and salvific-theological event than an event related to a given period; community in a situation that is opposed to salvation (Unheilsgemeinschaft) is presented as a fact and not as a biological determinant."

20 Doctrines referring to the "entanglement in sin" are developed in the collective work of four Austrian theologians: Ist Adam an allem schuld?, Erbsünde oder Sündenverflochtenheit?, Innsbruck 1971 (cf. the review of the author of present paper, which will be published in STV this year).

21 L. Stachowiak, Teologiczny..., art. cit., $38 \mathrm{ff}$.

22 Cf. esp. W.D. Davies, Paul and Rabbinic Judaism, London 1955, 20-35 and L. Stachowiak, art. cit., 41, including 26. 
Greek opposition between the soul and the body ${ }^{23}$ was expressed, which was not known in the Old Testament in this formulation ${ }^{24}$. However, if one were to consider this statement in the context of the possibility of martyrdom, one should not interpret its main meaning as an emphasis on the perspective of sustaining life by the immortal soul if the body dies, although it does not deny such a possibility. The immortal soul is not the very subject of salvation: it is the soul with the body, that is the whole person, revived by the resurrection, and only the whole person may be subject to eschatological death. Also here it is rather teaching about "what will happen after the martyr's death" than about the anthropological structure of a human being ${ }^{25}$.

One of Gächter's last major Catholic commentaries does not mention the anthropological meaning of this statement, and according to the text it should be regarded as a tightening of the obligation to profess faith in Jesus and the accompanying decision about choosing eternal life or rejection of $\mathrm{it}^{26}$.

The second assumption, often neglected in the anthropological discussions of the New Testament, is their Christological character. For the inspired authors the fullest expression of the endless sequence of human generations is Christ, the archetype of "new man" and the head of the new human community. Thus, the anthropological statements of the New Testament acquire a soteriological dimension at the same time. God's saving act realized through Christ is decisive for the inner renewal of man and for the profound change aimed at his eschatological resurrection: belonging to Him or the rejecting Him is expressed in anthropological terms.

From the point of view of Saint Paul, there is distinction between spirit and body ${ }^{27}$, new and old $\operatorname{man}^{28}$, "outer" and "inward" man (2 Cor 4:16), Saint John expresses the same view by the devaluation of all purely human aspects ${ }^{29}$ in favor of an affirmation of faith in the mission of Jesus Christ. The condition of man in the world is determined, according to the fourth Gospel, by his "heavenly origin," being a child of God contrasted with his worldly origin, which expresses

${ }^{23}$ Cf. L. Stachowiak, Biblijna..., art. cit., 211 and Theolog. Wörterbuch zum Neuen Test. vol. 7, 1025-1042.

${ }^{24}$ The exception is the book of Wisdom, where the influences of Greek philosophy are clearly visible in anthropology $(2,22 \mathrm{n}, 3,4)$.

${ }_{25}$ Cf. O. Schilling, Geist und Materie in biblischer Sicht, Stuttgart 1967, 59f.

26 P. Gächter, Das Matthäusevangelium, Innsbruck 1963, 343.

27 Cf. Theolog. Wörterbuch zum Neuen Test. vol. 7, 124-136.

28 Cf. Col. 3:10.

29 Cf. R. Bultmann, Theologie des Neuen Testaments, Tübingen 1954, 422. 
his belonging to Satan ${ }^{30}$. Saint John speaks little about the very process of man's rebirth in the anthropological sense; "Being born of God" (J 1:13; 1 I 2:29; 3:9; 4:7; 5:1), as well as being born "of heaven" (J 3:3) and of the "spirit" (J 3:5-6) basically expresses the soteriological idea ${ }^{31}$, although it is between the sphere of the body and the spirit, which he regards as the situation that determines the human condition, which is decisive for $\operatorname{man}^{32}$.

Finally, the third and extremely important factor in the proper orientation of biblical anthropology is the eschatological nature of life and the world in which man decides whether he would like to live according to the teaching of Christ or contrary to it. First of all, it should be noted that the New Testament is above all a mission of salvation and not of rejection, sin and eschatological death. Therefore, it is primarily about the decision to choose life, while the prospect of definitive death and rejection with all its realness highlight the absolute necessity and irreversibility of this very decision ${ }^{33}$. The eschatological situation in which a new man finds himself confronts him with a decision in which not only a superior part of him is involved, but the whole personality. Also, the consequences of this decision, such as resurrection, reward or eternal punishment, assume a biblical-holistic anthropological view. The genesis of the expectation of the eternal reward leads us to the theology of the Old Testament; it should be noted that it developed from the interpretation of the salvific perspective resulting from the Covenant, and not from the Greek soul-body dualism.

Admittedly, on the one hand, in claiming the immortality of the soul, it favored the justification of this teaching, and on the other hand it implied insurmountable difficulties in understanding the resurrection of the body because it used to have a definitely pejorative sense from the Greek point of view. It is the mention of the resurrection that caused the negative reaction of the listeners of Saint Paul in Athens (Acts 17:32), and the systematic study of it was a source of many difficulties for the Greeks at Corinth (1 Corinthians 15) ${ }^{34}$. Although

30

Cf. excursus 8 in: R. Schnackenburg, Die Johannesbriefe, Freiburg 19704, 175-183.

32 Cf. R. Meyer, Theolog. Wörterbuch zum Neuen Testament, vol. VII, 105-143 esp. 139 (incl. $\mathrm{J} 3: 6)$.

33 Cf. e.g. Mt 10:39. The perspective of the loss of temporal life emphasizes the postulate of an unconditional decision to live with Christ.

34 It should be noted that the New Testament never officially speaks of the "resurrection of the body" in the sense of the Greek sarx: the subject of the statement on this subject is always sôma (cf. Theol. Wörterb. zum N.T, Vol. VII, 1024- 91). In the Saint Paul's letters, the role of the body understood as sarx would be incompatible with its characteristics (see 1 Corinthians 15:15, where the Apostle states that "flesh and blood cannot attain the Kingdom of God."). The first 
referring to the synthesis of spirit and matter in the salvific eschatological $\operatorname{period}^{35}$ is consistent with the general orientation typical for Christian life described in the writings of the Saint Paul, it does not explain the anthropological process of the individual eschatological resurrection. The words of St. Paul 2 Cor 5:1ff express the hope of having an eternally permanent house of this tabernacle of God after this earthly house of this tabernacle were dissolved; but while remaining in this sanctuary and being granted the presage of the future life by the Holy Spirit, we would not want to lose this place, but "for in this we groan, earnestly desiring to be clothed upon with our house which is from heaven."

Here one can see that the mentioned statement undoubtedly concerns a future eschatology expected by the faithful in the near or longer term. In fact, even in the concept of present eschatology which can be found in the Fourth Gospel $^{36}$, the completion of eternal life already possessed is to be achieved in the future, so this can be considered the same moment of expectation which we can find in the writings of St. Paul. Due to the fact that man lives on earth as one psychophysical whole his eschatological future cannot take into account only one aspect of him, i.e. the purely spiritual side; indeed, both the body and spirit anticipate it in earthly life. The body, although it reminds man of his created and temporal nature, is fully susceptible to eschatological spirituality, which is, however, not synonymous with the loss of its physical character. Nevertheless, it is not possible to carry out further justification of this process within an anthropological framework.

One finds it difficult to consider relevant attempts made by contemporary theology as convincing ${ }^{37}$. The process of the resurrection of bodies in both individual and collective terms probably requires a further Christological justification. What is, however, crucial here is not a question whether or not one should regard Christ's glorified body that Saint Paul saw on the road to Damascus ${ }^{38}$ as the archetype of his words included in 1 Corinthians 15 and 2 Corinthians 5 but the fundamental theological truth about Christ who has been raised, the

texts stating anastasis tes sarkos (resurrection the body as a sarx) appear only in the Fathers: II Clem. 9,1; Justin, Dial. 80,5.

${ }_{35}$ Cf. O. Schilling, op. cit., 26-34.

36 Cf. esp. J. Blank, Krisis, Freiburg and Br. 1964.

37 Cf. e.g. M. Carrez, Mit was für einem Leibe stehen die Toten auf?, "Concilium" 6 (1970), 713-718. Other articles on this topic are included in the Polish version of "Concilium" 6-10 (1970), 222-243.

38 M. Carrez, art. cit., $716 f$. 
first fruits of those who have fallen asleep (1 Corinthians 15:20); and all believers will follow Him.

Perhaps the large-scale discussion in contemporary theology about the resurrection of Christ and the resurrection in general, will shed new light on the anthropological, or better, anthropological and theological conditioning of this object of Christian hope ${ }^{39}$. Many important theological theses reached their mature form and full justification among the conflicting extreme or even erroneous positions $s^{40}$. The aim of the review of anthropological issues carried out here was not supposed to exceed the hermeneutic framework of biblical anthropology, which is why it is far from taking into consideration all current issues. It presents rather material which is conditio sine qua non of constructive discussion than ready-made solutions whose orientation it can only imply. Above all, it was aimed at providing theology with biblical assumptions, formally spoken or assumed as obvious, and thus to contribute to a more complete understanding of the saving dialogue between God and man.

39 Cf. R. Schnackenburg, Zur Aussageweise "Jesus ist (von den Toten) auferstanden", "Bibl. Zeitschr. NF" 13 (1969), 1-17.

40 Much controversy is caused in particular by a monograph written by X. Léon -Dufoura Résurrection de Jésus et message paschal, Paris 1971. Cf. K. Sokołowski, [Z dyskusji nad zmartwychwstaniem Jezusa], RBL 25(1972)3-4, 219-229. 